\title{
Anti-diarrhoeal activities of the root bark methanol extract of Delonix regia in rats
}

\author{
Ode O. J. ${ }^{1 *}$, Ajagbonna, O. P. ${ }^{2}$, Madubuike, S. A. ${ }^{3}$, Oladele, G. M. ${ }^{1}$ and \\ Ayuba, U. B. \\ ${ }^{I}$ (Department of Veterinay Pharmacology and Toxicology, Faculty of Veterinary Medicine, University of Abuja, \\ Nigeria). \\ ${ }^{2}$ (Professor of Ethnopharmacology and Dean, Faculty of Veterinary Medicine, University of Abuja, Nigeria). \\ ${ }^{3}$ (Department of Veterinary Microbiology, Faculty of Veterinary Medicine, Ahmadu Bello University, Zaria,
}

Nigeria).

\begin{abstract}
The methanol extract of the root bark of Delonix regia was tolerated at the highest oral test dose of $4000 \mathrm{mg} / \mathrm{kg}$ in rats. The extract demonstrated significant anti-diarrhoea effects in three standard experimental models: castor oil-induced diarrhoea test, gastrointestinal motility test and castor oil-induced enteropooling test. The extract gave $61 \%$ and $89 \%$ inhibition of the experimentally-induced diarrhoea at 200 and $400 \mathrm{mg} / \mathrm{kg}$ respectively. In gastro-intestinal motility test, the transit point for $200 \mathrm{mg} / \mathrm{kg}$ extract was $24 \%$ and that of 400 $\mathrm{mg} / \mathrm{kg}$ extract was $26 \%$ compared to $44 \%$ in the control. In enteropooling test, the root bark extract also demonstrated appreciable potency at 200 and $400 \mathrm{mg} / \mathrm{kg}$ in suppressing intraluminal fluid accumulation with resultant reduction in the weight and volume of the rat intestinal contents. The effects of the extract could be due to increase in the absorption of electrolytes and inhibition of the hypermotility of the intestine. The results of the study did not only support the folkloric use of the plant in diarrhoea therapy but also revealed the root bark of D. regia as a potential source of novel anti-diarrhoeal agents.
\end{abstract}

Key words: Atropine, Delonix regia, Diarrhoea, Enteropooling, Loperamide.

\section{Introduction}

Diarrhoea as a major public health problem, contributes to a significant number of deaths in man and animals globally but more importantly in developing countries. The incidence of diarrhoea still remains high despite the efforts of many governments and international organizations to curb it. Worldwide distribution of diarrhoea accounts for more than 5-8 million deaths each year in children below 5 years of age [1]. In 1998 alone, deaths from diarrhoea were estimated at 7.1 million on a global scale [2]. In animals, the incidence is greatest in the first two weeks of life and there is considerable variation in incidence between herds. However, explosive outbreaks of diarrhoea can be a significant cause of mortality in certain years [3].

Diarrhoea is a symptom or complication of viral, bacterial, parasitic, protozoan infection, nutritional disease or intoxication [4]. Acute diarrhoea is associated with loss of body fluids and electrolytes leading to rapid dehydration, circulatory collapse and death, but in subacute form, it may persist for several days resulting in malnutrition and emaciation [5]. Most commonly used anti-diarrhoeal agents are known to have limitations or adverse effects such as tolerance that develops with the use of loperamide and diphenoxylate [6], urinary retention, gastric atony and intestinal ileus with atropine [7,8]. Again, the combination of several drugs such as gastric antacids, anticholinergics, analgesics, protectants, antibiotics and anti-inflammatory drugs in the chemotherapeutic management of diarrhoea is not only costly but may impair absorption and bioavailability of other drugs. In view of the poor efficacy of anti-diarrhoeal drugs, the World Health Organisation (WHO) advocated the use of herbal alternatives [9].

The root bark of D. regia is popularly used for treatment of non-specific diarrhoea by herbalists among the Igede tribe in Benue State - middle belt region of Nigeria. A high level of recognition is attached to the efficacy of the treatments. The decoction of the leaves is traditionally used in the treatment of gastric problems, body pain and rheumatic arthritis in parts of India [10]. Delonix regia synonymously called Poinciana regia Boj. Ex Hook, belongs to the family Fabaceae and Caesalpinioideae. It is commonly called 'dire dawa zaf' in Amharic; 'goldmore' in Arabic; flamboyant, flamboyant flame tree, flame of the forest, flame tree, royal poinciana' in English; 'flamboyant, poinciana royale' in French; 'gulmohr' in Hindi; 'sekeseke' in Yoruba [11] and 'Uhyila' in Igede tribe of Benue State, Nigeria. The plant is a very distinctive flamboyant tree with large bright red flowers and 10-15 m (maximum of $18 \mathrm{~m}$ ) high. It is regarded by some as the world's most colourful tree [12]. The plant flowers were documented to have antimicrobial $[13,14,15]$, hepatoprotective, antioxidant and antineoplastic activities [16, 17]. The stem bark, seeds, flowers and leaves exhibited antimalarial properties [18]; the flower and stem bark were found to have anti-inflammatory activities [19]. The leaves possess 
hypoglycemic effect in rats [20] while the seeds could be valuable as tablet binders [21]. The present study was to evaluate scientifically the anti-diarrhoeal activity of the root bark methanol extract of D. regia using conventional animal models.

\subsection{Experimental animals}

\section{Materials And Methods}

Matured inbred albino rats of both sexes weighing between 80-190 g were purchased from the Laboratory Animal unit of the College of Health Sciences, Benue State University, Makurdi. The rats were kept in the same room with a temperature varying between 28 and $30^{\circ} \mathrm{C}$; lighting period was between 15 and $17 \mathrm{~h}$ daily. The rats were kept in stainless steel wire mesh cages which separated them from their faeces to prevent coprophagy. They were supplied clean drinking water and fed standard feed (Grower mash pellets, Vital feeds ${ }^{\circledR}$, Nigeria). The animals were allowed two weeks to acclimatize prior to commencement of the experiments. The laboratory animals were used in accordance with laboratory practice regulation and the principle of laboratory animal care as documented by Zimmerman [22].

\subsection{Chemicals, reagents, drugs and equipment}

Freshly prepared solutions, analytical grade chemicals and reagents were used in the experiments. Methanol purchased from Sigma Aldrich, USA; atropine sulphate (Yanzhai Xierkangtai Pharma. Co. Ltd., China), hyoscine butyl bromide (Jiangsu Pengyao Pharmaceuticals Inc., China), loperamide (Imodium ${ }^{\circledR}$ ) from Johnson \& Johnson Ltd., Karachi, Pakistan; castor oil (Bell, sons \& Co., Druggists Ltd., Southport, England), electronic weighing balance (Furi, India), gum acacia and activated charcoal, test tubes, beakers, measuring cylinders, and intragastric lavage were used for the study. Charcoal meal was prepared and used as $10 \%$ activated charcoal in $5 \%$ gum acacia while loperamide, hyoscine butyl bromide and atropine sulphate were used as reference antidiarrhoeal drugs.

\subsection{Plant collection and identification}

Fresh roots of D. regia were collected from Ochimode village, Oju Local Government Area of Benue State, Nigeria in January, 2013. The plant roots were authenticated by Mr A.O. Ozioko, a taxonomist with Bioresources Development and Conservation Programme (BDCP), Aku road, Nsukka, Enugu State, Nigeria.

\section{4. Preparation and extraction of plant material}

The plant roots were washed in clean water and the bark carefully peeled off into a clean container using a kitchen knife. The plant material was dried under mild sunlight, and then reduced to coarse particles with mortar and pestle before been pulverized into fine particles using a laboratory hammer mill. The plant material was exhaustively extracted by cold maceration in $80 \%$ methanol with intermittent shaking at $2 \mathrm{~h}$ intervals for $48 \mathrm{~h}$. The extract was filtered and concentrated in vacuo using a vacuum rotary evaporator. The concentration and percentage yield of the extract were determined.

\subsection{Acute oral toxicity studies}

Acute toxicity studies were conducted using the method described by Lorke [23]. Thirty (30) matured Wistar rats of both sexes were marked with $10 \%$ picric acid, weighed and randomly separated into 6 groups (A - F) of 5 rats each. Groups A-E were given varying oral doses $(100 ; 250 ; 500 ; 1000 ; 2000$; and $4000 \mathrm{mg} / \mathrm{kg}$ ) of the root extract of D. regia respectively, while group F ( $6^{\text {th }}$ group) received an equivalent volume $(10 \mathrm{ml} / \mathrm{kg})$ of distilled water. All treatments were given orally by gastric intubation. The rats were observed for signs suggestive of toxicity within $72 \mathrm{~h}$. The animals that survived were further monitored for two weeks for toxic effects. The test was terminated after two weeks and all the animals were humanely sacrificed and postmortem examinations carried out on them.

\subsection{Castor oil-induced diarrhoea test}

The antidiarrhoeal activity of the methanol extract of D. regia was evaluated according to the method described by Teke et al. [24] with modification. Twenty adult albino rats of either sex were fasted for $22 \mathrm{~h}$ instead of $18 \mathrm{~h}$. They were marked, weighed and randomly allocated to five groups (I-V) consisting of four rats each. Group I served as the control and was given distilled water $(10 \mathrm{ml} / \mathrm{kg}$ ) orally; Group II (reference) was administered with loperamide ( $2 \mathrm{mg} / \mathrm{kg}$, per os); Groups III, IV and V were given graded doses $(100,200$ and $400 \mathrm{mg} / \mathrm{kg}$, p.o.) of the methanol extract of D. regia respectively. One hour after treatments, diarrhoea was induced with $1 \mathrm{ml}$ of castor oil given orally to each of the animals. The rats were observed for consistency of faeces and the frequency of defaecation. Faeces were collected on white sheets of paper placed beneath individual cages. The numbers of both wet and dry faecal droppings were counted every $1 \mathrm{~h}$ for a period of $4 \mathrm{~h}$; the white paper was changed periodically for each evaluation. The level of inhibition (\%) of wetness of faeces 
and the frequency of stooling caused by the extract was calculated relative to the control using the formula below:

Inhibition of defaecation (\%) = Mean No. of faeces of Control-Mean No. from treated Group x 100\% Mean No. of faeces of Control

\subsection{Gastro-intestinal Motility Test}

The effect of the methanol extract of D. regia on gastro-intestinal motility was evaluated using the method described by Mascola et al. [25]. Adult Wistar rats of either sex were fasted for $18 \mathrm{~h}$. The animals were marked, weighed and then separated into five groups comprising 4 rats per group. Each rat was given $1 \mathrm{ml}$ of castor oil orally to induce diarrhoea. After duration of $1 \mathrm{~h}$, animals in group I (control) received distilled water $(10 \mathrm{ml} / \mathrm{kg})$ per os. Group II was injected with atropine sulphate $(3 \mathrm{mg} / \mathrm{kg})$ intraperitoneally; Groups III, IV and $\mathrm{V}$ were treated orally with varying doses of the crude methanol extract of D. regia root bark. One hour following treatments, each group was given $0.2 \mathrm{ml}$ of charcoal meal $(0.5 \mathrm{ml}$ of $10 \%$ charcoal suspended in $5 \%$ gum acacia); and after a duration of $1 \mathrm{~h}$, the experimental rats were humanely sacrificed by cervical dislocation.

The small intestine of each rat was carefully separated from the mesenterium to avoid being overstretched. The length of the intestine from the pyloric sphincter to the ileo-caecal junction was isolated and the distance travelled by the charcoal meal was measured and expressed as percentage of the intestine from pylorus to caecum [26]. The position of the charcoal meal was regarded as the transit point and the mean for each treatment group was determined.

\subsection{Castor oil-induced Enteropooling test.}

The effect of D. regia root bark extract on diarrhoea was further studied using castor oil-induced enteropooling method [27]. Twenty matured albino rats which were fasted for $18 \mathrm{~h}$ were allocated randomly to five groups as previously described. Group I was given distilled water $(10 \mathrm{ml} / \mathrm{kg})$ orally; Group II received hyoscine butyl bromide (3 mg/kg, i.p.); Groups III, IV and V were treated orally with increased doses (100, 200 and $400 \mathrm{mg} / \mathrm{kg}$, p.o.) of the root bark extract of D. regia. One hour following treatments, each rat was given $1 \mathrm{ml}$ of castor oil. Two hours after induction of diarrhoea, the experimental rats were terminally sacrificed by cervical dislocation. The small intestine of each rat was located and tied at the pyloric and caecal junctions; it was then cut out with a scapel blade and weighed. The content of each intestine was collected by milking into a graduated test tube and the volume recorded. The empty small intestine was re-weighed and the difference in weight between the full and empty intestine was recorded as the weight of the small intestinal content [28]. The reduction in the volume and weight of the intestinal content for each group was calculated and expressed as percentage of the control value.

\subsection{Statistical analysis}

All data obtained from the experiments were expressed as mean \pm SEM (Standard error of the mean).The significance of differences among treatment groups was assessed using One-way analysis of variance (ANOVA) and Duncan Multiple range post hoc test. Differences at $p<0.05$ were considered significant.

\subsection{Description of the extract}

III. Results

The methanol extract of the root bark of D. regia was brownish in color and odourless. The extraction process gave a yield of $2.24 \% \mathrm{w} / \mathrm{w}$.

\subsection{Acute toxicity study of $D$. regia root bark extract in rats}

There were no deaths by the oral route even at the highest test dose of $4000 \mathrm{mg}$ per kg body mass. There were also no changes in faecal consistency within the period. At post mortem, there was no observable gross lesion in the liver, gastro-intestinal tract, spleen, heart and kidneys of the experimental rats.

\subsection{Castor oil-induced diarrhoea test}

Group I (control). Rats were given distilled water alone orally prior to induction of diarrhoea with $1 \mathrm{ml}$ of castor oil. The rats passed out enlarged mucoid faecal droppings with a mean frequency value of $4.5 \pm 2.2$ within $3 \mathrm{~h}$ of onset of diarrhoea (TABLE 1, PLATE 1). All the rats in this control group died at $3 \mathrm{~h}$ after induction of diarrhoea.

Group II (reference). Rats in this group were treated with a standard anti-diarrhoeal drug, loperamide (2 $\mathrm{mg} / \mathrm{kg}$ ) one hour before diarrhoea was induced with castor oil. There was $100 \%$ inhibition of diarrhoea and only dry faeces were produced (TABLE 1, PLATE 2). The rats survived the $4 \mathrm{~h}$ duration of the study following induction of diarrhoea. 
Group III. Animals were treated with low dose $(100 \mathrm{mg} / \mathrm{kg})$ of the root bark extract and after an hour, diarrhoea was induced as stated previously in group I. The extract gave a minimal gastro-protective effect as diarrhoea was inhibited by $22 \%$ with a frequency value of $3.5 \pm 1.8$ (TABLE 1, PLATE 3). However, in a similar response to treatment as in the control, all the test rats in the group died at $3 \mathrm{~h}$ after diarrhoea had commenced.

Group IV. Rats in the group received treatment with a medium dose $(200 \mathrm{mg} / \mathrm{kg})$ of the crude extract of the root bark of D. regia orally and one hour later, diarrhoea was induced in the experimental rats as stated above in group I. The extract exerted $61 \%$ inhibition of diarrhoea with a reduced frequency value of $1.6 \pm 1.0$ (TABLE 1, PLATE 4); faecal droppings became more semi-solid in consistency compared to the control at $3 \mathrm{~h}$ after onset of diarrhoea. All the rats survived the $4 \mathrm{~h}$ duration of the study.

Group V. Animals in this group were pre-treated with a high dose (400 mg/kg, p.o.) of D. regia root bark extract $1 \mathrm{~h}$ prior to onset of castor oil-induced diarrhoea. There was $89 \%$ inhibition of diarrhoea caused by the laxative effects of castor oil given orally to the rats. The faecal droppings became more solid compared to those of control and other groups with a remarkably reduced frequency value of $0.5 \pm 0.5$ (TABLE 1, PLATE 5). The rats in the group were all alive till the end of the experiment.

Table 1

\begin{tabular}{|c|c|c|}
\hline Group Treatment & Number of wet defaecation in $3 \mathrm{~h}$. & $\%$ inhibition of diarrhea \\
\hline I: Control (distilled water $(10 \mathrm{ml} / \mathrm{kg})$ & $4.5 \pm 2.2++$ & 0 \\
\hline II: Loperamide ( $2 \mathrm{mg} / \mathrm{kg}$, p.o.) & 0.0 & $100^{*}$ \\
\hline III: D. regia RB extract $(100 \mathrm{mg} / \mathrm{kg}$, p.o. $)$ & $3.5 \pm 1.8++$ & $22^{*}$ \\
\hline IV: D. regia RB extract $(200 \mathrm{mg} / \mathrm{kg}$, p.o. $)$ & $1.6 \pm 1.0$ & $61^{*}$ \\
\hline$V: D$. regia $R B$ extract $(400 \mathrm{mg} / \mathrm{kg}, \mathrm{p}$.o.) & $0.5 \pm 0.5$ & $89^{\circ}$ \\
\hline
\end{tabular}

Values are mean \pm S.E.M, $n=4$; "Significant when compared to control at $p<0.05$; + death of all rats at $3 \mathrm{~h}$ after onset of diarrhea.

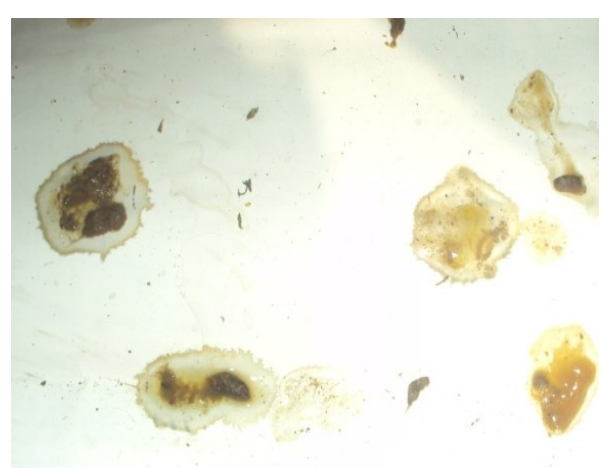

Plate 1: Diarrhoea from control rats.

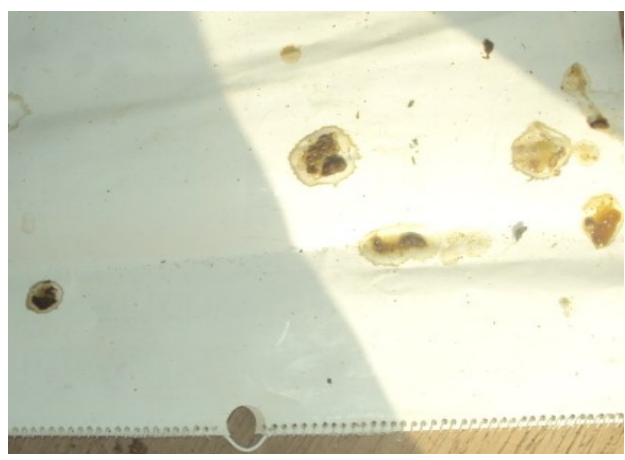

Plate 3: Diarrhoea inhibited by $22 \%$ with D. regia root bark extract $(100 \mathrm{mg} / \mathrm{kg})$.

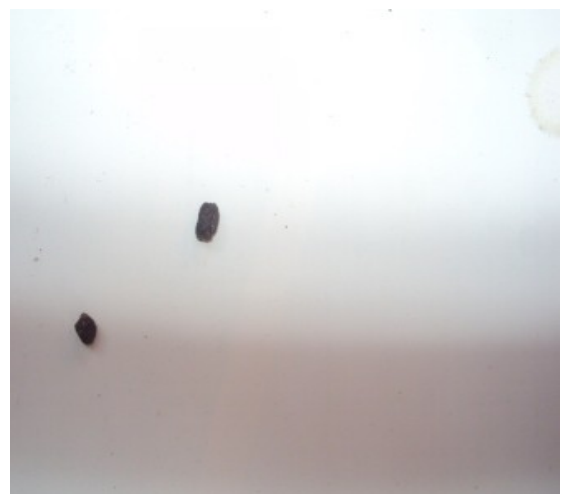

Plate 2: Complete (100\%) inhibition of diarrhoea with loperamide $(2 \mathrm{mg} / \mathrm{kg})$.

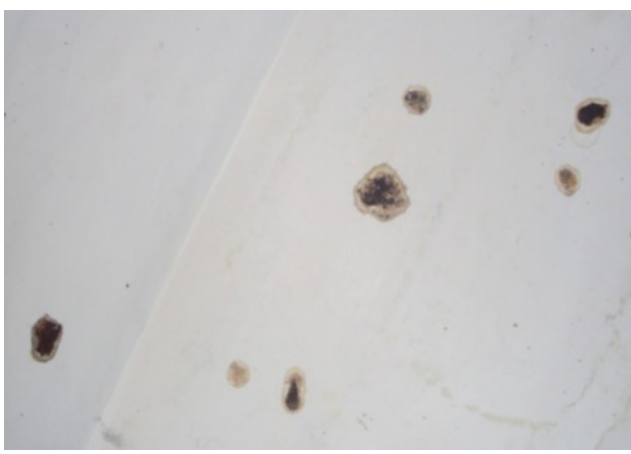

Plate 4: Diarrhoea inhibited by $61 \%$ with D. regia root bark extracts $(200 \mathrm{mg} / \mathrm{kg})$. 


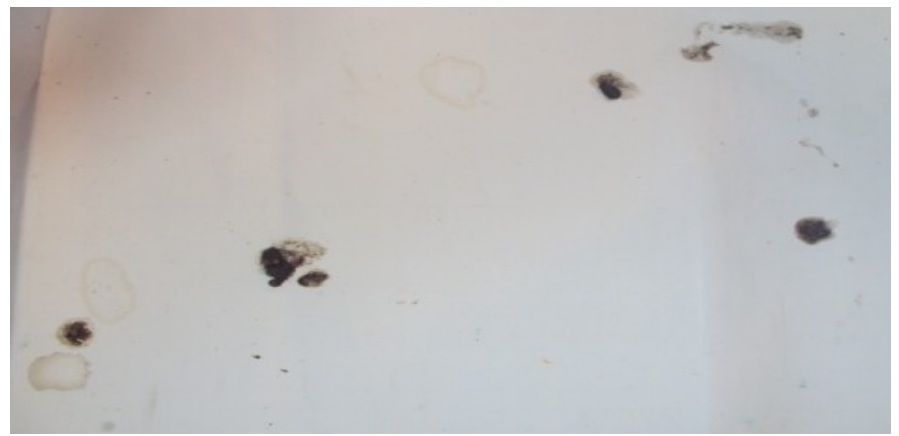

Plate 5: Diarrhoea inhibited by $89 \%$ with D. regia root bark extract $(400 \mathrm{mg} / \mathrm{kg})$.

\subsection{Gastro-intestinal motility test}

The effect of distilled water (control), atropine sulphate, and graded doses (100, 200 and $400 \mathrm{mg} / \mathrm{kg}$ ) of the methanol extract of D. regia root bark on charcoal meal test in rats is shown in Fig. 1 and PLATE 6 below. The charcoal meal was found to have moved the longest mean relative distance of $0.44 \pm 0.10 \mathrm{~cm}$ (a transit point of $44 \%$ ) within the intestinal lumen of control (untreated) rats that received distilled water alone prior to induction of diarrhoea. The transit point of $32 \%$ in low dose $(100 \mathrm{mg} / \mathrm{kg})$ extract-treated rats is not significantly ( $>0.05$ ) different from that of the control with a transit point of $44 \%$. But the charcoal meal travelled through significantly $(<0.05)$ reduced mean relative distances in rats that were pre-treated with atropine sulphate $(3$ $\mathrm{mg} / \mathrm{kg}$ ), 200 and $400 \mathrm{mg} / \mathrm{kg}$ of the extract before the onset of the experimentally-induced diarrhoea compared to the control and low dose of the extract. The transit points produced by atropine and the extract at 200 and 400 $\mathrm{mg} / \mathrm{kg}$ were 17,24 and $26 \%$ respectively.

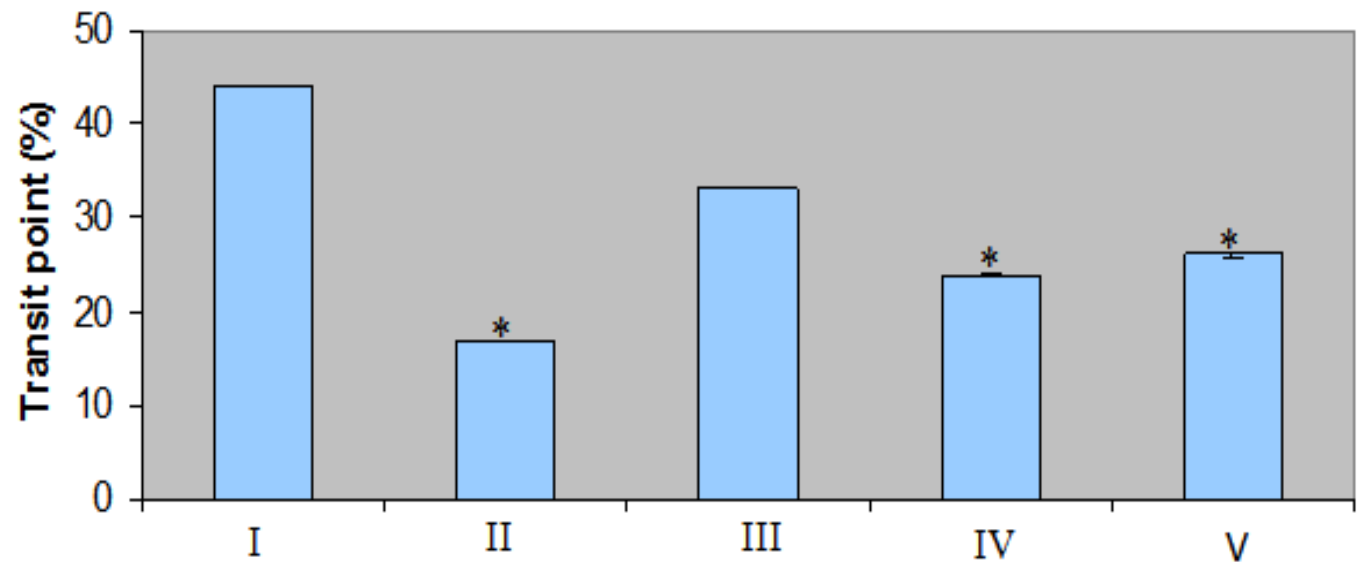

$\mathrm{I}=$ Control (distilled water); II = Atropine sulphate $(3 \mathrm{mg} / \mathrm{kg}) ; \mathrm{III}=$ D. regia root bark extract $(100$ $\mathrm{mg} / \mathrm{kg}) ; \mathrm{IV}=D$. regia root bark extract $(200 \mathrm{mg} / \mathrm{kg}) ; \mathrm{V}=D$. regia root bark extract $(400 \mathrm{mg} / \mathrm{kg}) ;$ *significant difference $(\mathrm{p}<0.05)$ when compared with control.

Figure 1: Effects of D. regia root bark extract $(100-400 \mathrm{mg} / \mathrm{kg})$ on intestinal motility.

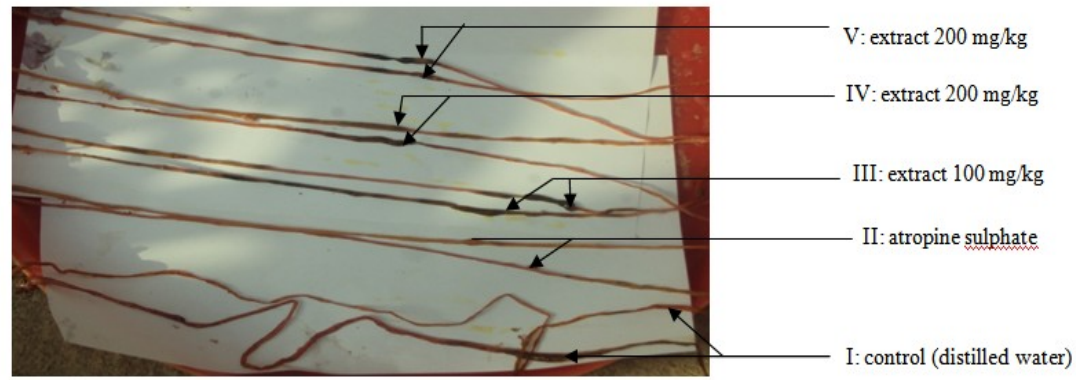

The intestines of control rats were folded for the lengthy position of the charcoal meal to be brought into better focus. II: atropine-treated rat intestines apparently without movement of charcoal meal.

Plate 6: Positions of the charcoal meal in the intestine of different rat groups in gastro-intestinal motility test. 


\subsection{Castor oil-induced Enteropooling Test}

Hyoscine butyl bromide $(3 \mathrm{mg} / \mathrm{kg}$, i.p.) treatment reduced the weight of the rat intestinal contents by $58 \%$ (Group II) but the extract $(100,200$ and $400 \mathrm{mg} / \mathrm{kg}$ ) produced a respective $20 \%, 34 \%$ and $37 \%$ reduction in the weight of intestinal contents (Groups III, IV and V). The root bark extract of D. regia caused a significant $(\mathrm{p}<0.05)$ dose dependent reduction in the weight of the intestinal contents (The mean weight of the intestinal contents for control $=1.50 \pm 0.1 \mathrm{~g}$; hyoscine butyl bromide $=0.65 \pm 0.1 \mathrm{~g} ; 100 \mathrm{mg} / \mathrm{kg}$ extract $=1.2 \pm 0.3 \mathrm{~g} ; 200$ $\mathrm{mg} / \mathrm{kg}$ extract $0.98 \pm 0.1 \mathrm{~g}$ and $400 \mathrm{mg} / \mathrm{kg}$ extract $=0.93 \pm 0.1)$. However, there was no significant $(\mathrm{p}>0.05)$ difference in the weight of intestinal content of rats that were treated with $100 \mathrm{mg} / \mathrm{kg}$ of the extract and the control (Fig. 2).

In the same manner, the mean volume of intestinal content in the control was $1.20 \pm 0.1 \mathrm{~cm}^{3}$ relative to $0.45 \pm 0.1 \mathrm{~cm}^{3}$ with hyoscine butyl bromide $(3 \mathrm{mg} / \mathrm{kg}), 0.90 \pm 0.2 \mathrm{~cm}^{3}$ with $100 \mathrm{mg} / \mathrm{kg}$ of the extract, $0.63 \pm 0.1$ $\mathrm{cm}^{3}$ with $200 \mathrm{mg} / \mathrm{kg}$ of the extract and $0.65 \pm 0.1 \mathrm{~cm}^{3}$ with $400 \mathrm{mg} / \mathrm{kg}$ of the extract. Accordingly, hyoscine butyl bromide caused $62.5 \%$ reduction in the mean volume of the intestinal content of rats in group II while animals in groups III-V that were given treatment with graded doses $(100,200$ and $300 \mathrm{mg} / \mathrm{kg})$ of the extract had $25 \%, 48 \%$ and $46 \%$ reduction respectively (Fig. 2$)$. There was a significant $(\mathrm{p}<0.05)$ reduction in the volume of the intestinal content of rats that were treated with hyoscine butyl bromide $(3 \mathrm{mg} / \mathrm{kg})$ and high doses (200 and $400 \mathrm{mg} / \mathrm{kg}$ ) of the root bark extract of D. regia compared with the control value. Again, there was no significant ( $>0.05$ ) difference between the volume of intestinal content of rats that were treated with $100 \mathrm{mg} / \mathrm{kg}$ of the extract and the control group.

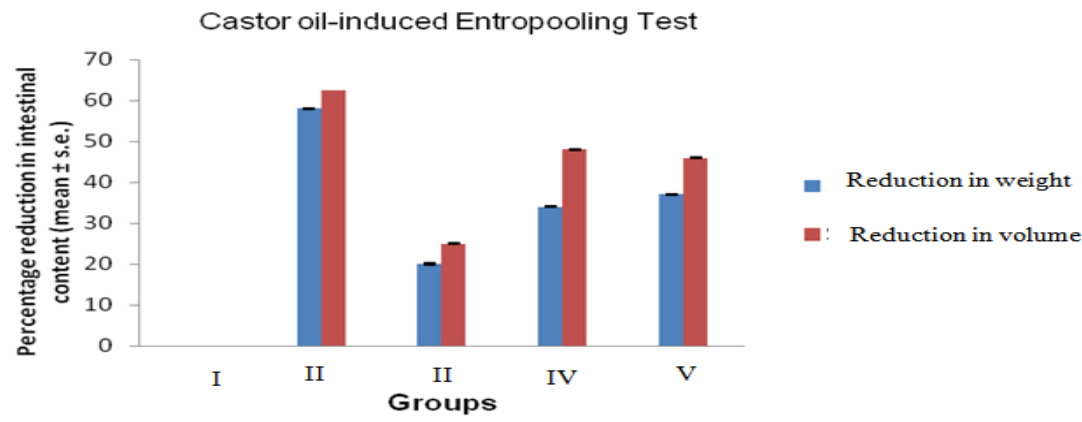

I: Control (distilled water); II: Hyoscine (3 mg/kg); III: D. regia root bark extract (100 mg/kg);

IV: D. regia root bark extract $(200 \mathrm{mg} / \mathrm{kg}) ; \mathrm{V}:$ D. regia root bark extract $(400 \mathrm{mg} / \mathrm{kg})$.

Figure 2: Effects of $D$. regia root bark extract $(100-400 \mathrm{mg} / \mathrm{kg})$ on intestinal content of rats in castor oil-induced entropooling test

\section{Discussion}

The extraction of D. regia root bark gave a low yield of 2.24 percent; this could be due to the high fibre content of the plant material. The crude extract did not cause mortality in the experimental rats even at the highest oral dose of $4000 \mathrm{mg} / \mathrm{kg}$, an indication that the extract was less toxic by this route. This was further supported by the absence of gross lesions in post mortem examinations.

In castor oil-induced diarrhoea test, $1 \mathrm{ml}$ of castor oil produced enlarged faecal droppings in untreated (control) rats (PLATE 1) relative to other treatment groups. Loperamide $(2 \mathrm{mg} / \mathrm{kg})$ and the various doses $(100$, 200 and $400 \mathrm{mg} / \mathrm{kg}$ ) of the extract gave $100 \%, 22 \%, 61 \%$ and $89 \%$ inhibition of the experimentally-induced diarrhoea respectively. The extract produced a dose dependent inhibition of castor oil-induced diarrhoea with a maximal effect of $89 \%$ at $400 \mathrm{mg} / \mathrm{kg}$ (TABLE 1). The anti-diarrhoeal effects of the extract at higher doses was further demonstrated when all the experimental rats in the control and low dose $(100 \mathrm{mg} / \mathrm{kg})$ of the extract died at $3 \mathrm{~h}$, but the rats treated with the extract $(200$ and $400 \mathrm{mg} / \mathrm{kg}$ ) and loperamide survived the duration $(4 \mathrm{~h})$ of the study. The death of the rats further lends credence to the anti-diarrhoeal effects of the extract at high doses (200 and $400 \mathrm{mg} / \mathrm{kg}$ ). In the test, loperamide, an opioid had 100 percent protective effect on the castor oilinduced diarrhoea. Loperamide has a selective action on the gastro-intestinal tract where it undergoes significant enterohepatic circulation and reduces the frequency of passage of faeces. The main opioids used in diarrhoea are difenoxin, diphenoxylate and loperamide (Imodium). Opioids act on enteric nerves, epithelial cells and muscle through $\mu$ receptors to elicit intestinal motility, $\delta$ receptors for intestinal secretion, and both receptors for absorption [29].

Castor oil was used to induce diarrhoea and it forms ricinoleic acid which is liberated by the action of lipases on castor oil. Ricinoleic acid is an active compound in the upper intestinal tract but poorly absorbed. It produces irritating and inflammatory actions on the intestinal mucosa leading to the release of prostaglandins [30]. This condition induces an increase in the permeability of the mucosal cells and changes in electrolyte 
transport, which results in a hyper-secretory response (decreasing $\mathrm{Na}+$ and $\mathrm{K}+$ absorption), stimulating peristaltic activity and diarrhoea [31]. Inhibitors of prostaglandin synthesis are known to delay onset of diarrhoea induced with castor oil [32]. Castor oil is also reported to induce diarrhoea by increasing the volume of intestinal content and prevention of the reabsorption of water [33].

In the evaluation of intestinal transit, the extract appeared to act on all parts of the intestine. As seen in Fig. 1, it reduced the intestinal propulsive movement of the charcoal meal at all doses: Transit points for atropine sulphate $=17 \%, 100 \mathrm{mg} / \mathrm{kg}$ extract $=32 \% ; 200 \mathrm{mg} / \mathrm{kg}$ extract $=24 \% ; 400 \mathrm{mg} / \mathrm{kg}$ extract $=26 \%$. The anti-motility effect of the extract was not comparable to that of atropine sulphate, and this is logical since atropine sulphate is a pure compound but the extract is crude and a mixture of many compounds. Atropine sulphate, a known muscarinic receptor antagonist and antispasmodic agent was used as the standard drug. It decreases intestinal spasms by inhibiting parasympathetic activity. Anticholinergics (atropine, hyoscine (scopolamine), propantheline, isopropamide) act as antagonists at central and peripheral muscarinic receptors $\left(\mathrm{M}_{1}\right.$ and $\left.\mathrm{M}_{2}\right)$. The effect on $\mathrm{M}_{2}$ receptors potentially causes delayed gastric emptying and ileus [7]. Loperamide is also as an antimotility agent and it diminishes the propulsive activity of the gut [34].

Studies made on activated charcoal showed that it prevents absorption of drugs and chemicals into the system by adsorbing them on the surfaces of charcoal particles. Activated charcoal was used in the gastrointestinal motility test to find out the effects of the extract on the peristaltic movement. The results showed that the root bark methanol extract of D. regia suppressed gastro-intestinal motility and propulsion of the charcoal meal maximally at 200 and $400 \mathrm{mg} / \mathrm{kg}$ (probably in the same way as atropine) and thereby increased the time for absorption of water and electrolytes.

In the enteropooling study, the extract exerted a remarkable effect in reducing the intestinal content of the rats. The intraluminal fluid accumulation was significantly blocked. The intestinal fluid secretion induced by castor oil was reduced by 48 and 46 percent at 200 and $400 \mathrm{mg} / \mathrm{kg}$ of the extract respectively (Fig. 2). This suggests that the effects of the extract may be due to an increase in the absorption of electrolytes coupled with inhibition of the hypermotility of the intestine. The capacity the rat intestines to retain fluids was thereby improved, an action similar to that of loperamide. Some diarrhoeagenic agents like magnesium sulphate, castor oil, bile, tauracholate and taurochenodesoxycholate cause enteropooling. The anticholinergic agent, methyl scopolamine but in the test, hyoscine butyl bromide partially counteracted enteropooling. The assay therefore could be used to assess the laxative or antidiarrhoeal activity of compounds [35].

\section{Conclusion}

From the results of the study, it could be concluded that D. regia root bark possesses pharmacologically active substance (s) with anti-diarrhoeal properties. The use of the plant material in folklore medicine to treat diarrhoea is therefore rational. Further studies are on-going to isolate, identify and elucidate the bioactive principle(s) responsible for the observed effects and to fully investigate the mechanism of actions.

\section{Acknowledgements}

The authors wish to sincerely thank Mr. A.O. Ozioko of Bioresources Development and Conservation Programme, Nsukka, Enugu State, Nigeria for identifying the plant sample.

\section{References}

[1] A.S. Fauci, E. Bravnwold, K. Isselpacker, J.D.Wilson, D.L. Kasper, and S.L Hauser et al., Harrison's Principles of Internal Medicine (New York: McGraw Hill Company, 1993) 236-242.

[2] K. Park, Park's Textbook of Preventive and Social medicine (Jabalpur, India: M/S Banarsidas Bharat Publishers, 2000) $172-175$.

[3] D. Greenwood, R. Slack, J. Peutherer, and M. Barer, Medical Microbiology, 7 (Edinburgh: Churchill Livingstone, 2007$)$ 154-164.

[4] A. E. Susan, and M. ASA (Eds.), Pharmacology, in The Merck Veterinary Manual, 8 (New Jersey: Merck \& Co. Inc., 1998) 1685 1687.

[5] C.E. Greene, Infectious diseases of dog and cat, 3 (Missouri, USA: Saunders Elsevier, 2006) 63-368

[6] F.S.K. Barar, Essentials of Pharmacotherapeutics (New Delhi, India: S. Chand \& Company, 2005) 540-542.

[7] J.E. Maddison, S.W. Page, and D. Church, Small Animal Clinical Pharmacology (London: W.B. Saunders, 2002 ) 434.

[8] K. Bimelsh, D. Kalyani, T. Prashant, S. Manoj, and G. Diwakar, Evaluation of antidiarrhoeal effect of aqueous and ethanolic extracts of fruit pulp of Terminalia belerica in rats. Int. J. Drug Dev. Res., 2(4), 2010, 769-779.

[9] J. D. Synder, and M. H. Merson, The Magnitude of the global problem of acute diarrhoeal disease, A review of active surveilla nce data, Bulletin of the World Health Organisation, 60, 1982, $604-613$.

[10] J. A. Parrota, Healing of Plants of Peninsular India (New York, USA: CABI publications, 2000) 3-250.

[11] S.H. Brown, A report of the Institute of Food and Agricultural Sciences (IFAS) Extension. US Department of Agriculture, Cooperative Extension Service, University of Florida, 2011.

[12] R. W. J. Keay, C. F. A. Onochie, and D. P. Stanfield, Nigerian trees (London: Macmillan Press, 1964$)$ 3-68.

[13] F. Aqil, M.S. Khan, M. Owais, and I. Ahmad, Effect of certain bioactive plant extracts on clinical isolates of beta-lactamase producing methicillin resistant Staphylococcus aureus, Methods Find. Exp. Clin. Pharmacol., 29 (2), 2007, 79-92.

[14] I. Jahan, M.S. Rahman, M.Z. Rahman, M.A. Kaisar, M.S. Islam, A. Wahab, and M.A. Rashid, Chemical and biological investigation of Delonix regia (Bojer ex Hook.) Raf. Acta Pharm., 60 (2), 2010, 207-15.

[15] R.A. Sharma, S. Chandrawat, S. Sharma, D. Sharma, B. Sharma, D. Singh, Efficacy of Delonix regia Rafin (Syn. Poiciana regia Bojer Ex. Hook) for potential antifungal activity, The Bioscan, 5 (3), 2010, 41-444. 
[16] M.E. Aly, M.E. Shahira, M.S. Maha, and A.S. Amany, Hepatoprotective and cytotoxic activities of Delonix regia flower extracts, Pharmacognostic, J., 3 (19), 2011, 49.

[17] I. Shanmukha, P. Harshil, P. Jignesh, and Riyazunnisa, Quantification of total phenol and flavonoid content of Delonix regia flower, International J. Chem. Tech. Research, 3 (1), 2011, 283.

[18] N.A. Ankrah, A.K. Nyarko, P.G. Addo, M. Ofosuhene, C. Dzokoto, E. Marley, M.M. Addae, and F.A. Ekuban, Evaluation of efficacy and safety of a herbal medicine used for the treatment of malaria, Phytotherapy Research, 17 (6), 2003, 697-701.

[19] K. N. Muruganandan, K. Srinivasan, and S. Chandra, Anti-inflammatory and analgesic activity of some medicinal plants. Journal of Medicinal and Aromatic Plant Sciences, 22, 2001, 56-58.

[20] R. Mahafuzur, H. Nazmul, K. D. Asish, H. Tozammal, J. Rownock, and K. Afsana, et al., Effect of Delonix regia leaf extract on glucose tolerance in glucose induced hyperglycemic mice, African Journal of Traditional, Complementary and Alternative Medicine, 8(1), 2011, 34-36.

[21] G.E. Adetogun, and G. Alebiorun, Properties of Delonix regia seed gum as a novel tablet binder, Acta Pol. Pharm., 66 (4), 2009, 433-8.

[22] M. Zimmermann, Ethical guidelines for investigations of Experimental pain in Conscious Animals, Pain, 16, 1983, 109-110.

[23] D. Lorke, A new approach to practical acute toxicity testing, Archi. Toxicol. 54, 1983, 275-287.

[24] G. N. Teke, J. R. Kuiate, O.B. Ngouateu, and D. Gatsing, Antidiarrhoeal and antimicrobial activities of Emilia coccinea (Sims) G. Don Extracts. Journal of Ethnopharmacology, 112, 2007, 278-283.

[25] N. Mascola, A.A. Izzo, G. Avtore, R. Barboto, and F. Cappasso, Nitric oxide and castor oil induced diarrhoea, Journal of Pharmacology and Experimental Therapeutics, 268, 1994, 291-295.

[26] A. A. Izzo, N. Mascolo, R. Capasso, M.P. Germano, R. Depasquel, and F. Capasso, Inhibitory effect of caannabinoid agonists on gastric emptying in the rat, Archives of Pharmacology, 360, 1999, 221-223.

[27] A. Robert, J.E. Nezamis, C. Lancaster, A.J. Hanchar, and M.S. Klepper, Enteropooling assay, a test for diarrhoea produced by prostaglandins, Prostaglandins, 11, 1976, 809-828.

[28] S.W.R. Inayathulla, A. A. Karigar, and S. Mukesh, Evaluation of anti-diarrhoeal activity of Crataeva nurvala root bark in experimental animals, International Journal of Pharmacy and Pharmaceutical Sciences, 2, 2005, 158-161.

[29] L. Brunton, K. Parker, D. Blumenthal and I. Buxton, Goodman \& Gilman's Manual of Pharmacology and Therapeutics (New York: McGraw Hill Companies, 2008) 424-650.

[30] K., S. Yoshio, B. M. Kazuko, H. Kazunori, I. Atsushi, and K. Yasuhiro, Relationship between antidiarrhoeal effects of HangeShashin-To and its active components, Phytotherapy Research. 13, 1999, 468-473.

[31] M. Zavala, C. P'erez, R. Vargos, and M. P'erez, Antidiarrhoeal activity of Waltharia americana, Commelina coelestis and Althernan repens, Journal of Ethnopharmacology, 61, 1998, 41-47.

[32] J. A. J. Sunilson, K. Anandaeajagopal, A.V.A. G. Kumari, and S. Mohan, Antidiarrhoeal activity of Leaves of Melastoma malabathricum Linn, Indian Journal of Pharmaceutical Science, 6, 2009, 691-95.

[33] S. P. Pampattiwar, and N. V. Advani, Evaluation of anti-diarrhoeal activity of Ficus glomerata in castor oil induced diarrhoea in rats, Journal of Science, 1, 2011, 26-30.

[34] H.P. Rang, M .M. Dale, J. Ritter, and P. K. Moore, Pharmacology, 5 (London: Churchill Livingstone, 2003$) 376-584$.

[35] J. E. Shook, T. F. Burks, J.W.F. Wasley, and J. A. Norman, Novel calmodulin antagonist CGS 9343B inhibits secretory diarrhoea, J Pharmacol Exp Ther, 251, 1989, 247-252. 